\title{
Critical Systems Development - Ramifications for Management
}

\author{
Alan Underwood \\ $Q U T$, \\ GPO Box 2434, Brisbane Qld 4127, Australia \\ Telephone: 61738642515 Facsimile: 61738641282 \\ e-mail:alanu@fit.qut.edu.au
}

\begin{abstract}
This paper addresses the legal liability of developers of critical software systems in Australia and in so doing highlights the ramifications for management in accepting legal responsibility for their safe and reliable operation. The discussion focuses on the obligations imposed under the Trade Practices Act with the recent inclusion of product liability laws prompted by the 1985 EC liability directive. The increased emphasis on the liability of developers for the safe operation of their software reflects similar moves throughout the European Communities.
\end{abstract}

\section{Keywords}

Product liability, security/safety-critical software systems, state-of-the-art legal defence

\section{INTRODUCTION}

The proclamation of the 25 July 1985 European Communities Council Directive, concerning liability for defective products, should have alerted managers and software developers worldwide regarding their increased responsibility to the consumers (users) of their software products.

The thrust of the European Communities (EC) directive was that a producer of a product would be held liable to any person who suffered injury, or whose property was damaged, because of a defect in the product. Article six of the directive [EC 1985] considers a product defective "...when it does not provide the safety which a person is entitled to expect ..."

On 13 May 1991, the Australian Minister for Justice and Consumer Affairs, Senator Michael Tate, announced that the Federal Cabinet had agreed to introduce new Product Liability Laws based on the 1985 EC directive. The new laws were expected to supplement, rather than substitute for, the then common law position under the Trade Practices Act [1974]. Subsequently a new Part VA, Liability of Manufacturers and Importers for Defective Goods, was inserted into the Trade Practices Act in 1992. The Explanatory Memorandum to the new Part summarised the situation as follows: 
"The key concept of the new Pt VA ... is that a person who is injured, or whose property is damaged by a defective product will have a right to compensation against a manufacturer of the product. Goods are 'defective' if they do not have the degree of safety which persons generally are entitled to expect in all circumstances...

The manufacturer can escape liability where it can prove one of several defences. The most significant defence is that the goods were not defective when supplied by the manufacturer or that the goods were 'state of the art'."

\section{PRODUCT LIABILITY}

Product liability is the liability placed upon a manufacturer to ensure that the products that are released to the public for consumption or use are not defective. If the products are found defective then it is the liability that arises from such defects.

Inevitably in discussing product liability the tort of negligence will be involved. In lay terms negligence equates to carelessness. The legal meaning of negligence involves the following three elements:

(a) the existence of a duty of care owed by the defendant to the plaintiff; and

(b) a breach by the defendant of that duty; and

(c) damage or loss suffered by the plaintiff.

A software developer's failure to take due care in the development of software products, thus leaving open a case for negligence, would be present where, for example:

- $\quad$ a software developer failed to verify the quality of code before delivery;

- $\quad$ there was a foreseeable risk of physical damage to individuals as a result of the failure; and

- $\quad$ physical damage to individuals resulted.

Breach of the duty of care may be in the form of a primary breach by the developers failing to establish proper working practices, or may be vicarious where an employee of the developer failed to exercise proper personal care in performing the work.

The landmark decision related to manufacturers' liability in Common Law was handed down in 1932 when the case of Donoghue $v$ Stevenson ${ }^{1}$ was decided. Previously the Courts had accepted that a duty of care only existed if there was some privity of contract in place. As a result of this case, an important new principle known as 'the neighbour principle' was established. This principle meant that the manufacturer had a legal duty to take reasonable care of a legal 'neighbour'. In other words the legal duty can arise independently of any contract between the people involved.

The 'neighbour principle' has been the foundation of product liability law with a trend in the 1980's to widen the principle in both Australia and England so that the court had greater flexibility. An important aspect in a cause of action for negligence is that the onus of proof is upon the plaintiff to show that the manufacturer has been negligent in the supply of the defective goods. The EC Liability Directive introduced a dramatic shift in the onus of proof.

2 The case concerned a woman who sued a soft drink manufacturer after drinking ginger beer from a bottle that contained a decomposed snail. The court held that the fact that there was no contractual relationship between the plaintiff and the defendant did not stop the plaintiff from suing someone for tort. 


\section{TRADE PRACTICES}

The Trade Practices Act 1974 is an Act of the Commonwealth Parliament and applies where a seller is a corporation and, where the buyer is a consumer, as defined in the Act. Part V of the Act, Consumer Protection, is aimed at protecting the position of consumers in their dealings in the marketplace.

If the Trade Practices Act does not apply, an individual in Queensland, for example, must rely on either the Sale of Goods Act 1896, or the Hire Purchase Act 1959. The Sale of Goods Act, as its name implies, only applies to goods as defined in the Act and does not apply to services. The Hire Purchase Act only applies where the goods are hired under a hire purchase agreement as defined in the Act. Under either of these Acts a person paying for services does not have any rights against the service provider but rights would exist under the Trade Practices Act.

Unfortunately the Australian legal system has yet to clarify whether computer software is classifiable as 'goods' under the Trade Practices Act. The Act implies into some contracts terms relating to, among other things, the quality, fitness and suitability of 'goods' and 'services'. The question as to whether computer hardware and software are goods for the purposes of the Act was considered in the 1983 case of Toby Construction Products Pty. Limited v Computa Bar Sales Pty. Limited. The case involved a contract for three items of hardware and two of software [Healey 1993]. Justice Rogers of the New South Wales Supreme Court stated that in light of the inclusive nature of the definition of "goods," the real question was whether the sale of the equipment was a "sale of goods" in the ordinary sense of those words. His Honour decided that the system, including software, could be bought mass produced and "off the shelf." The sale was of tangible chattels, and the fact that the software was included did not preclude this description. His Honour stated that the classification of a sale of software alone as a sale of goods was a "debatable question."

A subsequent case involved the supply of electronic data by the Australian Stock Exchange to subscribers. Justice Wilcox ruled that there was a legislative intention to include "electricity" within the definition of "goods." Data, on the other hand, were not "goods" within the meaning of the Act. This view was overturned on appeal. Thus, the issue of whether software on its own is regarded as 'goods' in Australia has yet to be judicially decided to avoid threshold definition issues in litigation under the Trade Practices Act.

The legal system however is based on precedent and a recent decision in England reinforces the thesis of this paper that software developers will increasingly be held liable for defective software. Hall [1995] reports the case of St Albans City and District Council v International Computers Limited decided in London in October 1994 in which the High Court of England and Wales considered the contract under which ICL had supplied a computer system to calculate local taxes. An error in the supplied software caused St Albans City Council to over-estimate its number of tax payers. Based on this estimate the Council set a tax rate for the year that was too low resulting in a shortfall of $£ 1.3 \mathrm{~m}$. Subsequently the council sued ICL for the loss.

The judge ruled in favour of the Council stating that "programmes are, of necessity, contained in some physical medium, otherwise they are useless...It is just as much a supply of goods as if paint were applied to a wall or printing ink to a blank page. It is not simply abstract information, like information passed by word or mouth...If supply of software is not a supply of goods, it is difficult to see what it can be. My conclusion is that it is a supply of goods".

The latter ruling is interesting in light of the Australian judgments since the English judge 
did not distinguish between the software and the physical medium on which it was supplied. There would also appear to be some similarity to the Australian 1983 case of Toby Construction Products Pty. Limited v Computa Bar Sales Pty. Limited in that the judgment appears more relevant to "off the shelf" software packages rather than to custom built software designed specifically for a particular client's application. Hall [op. cit.] suggests that the development of customised packages seems to more closely reflect the supply of professional services than the selling of goods. ICL has announced that it would appeal.

Division 2A of Part 5 of the Trade Practices Act deals with actions against manufacturers or importers of goods. It imposes liability on manufacturers who supply goods to consumers which:
1. do not correspond to their description;
2. are unmerchantable quality;
3. do not conform to sample;
4. are unfit for stated purpose;
5. do not comply with certain express warranties.

As with the law of negligence the onus of proof is placed upon the consumer to prove that the manufacturer has contravened Division 2A.

This burden of proof is at odds with the intent of the EC product liability directive. Senator Tate had based his original proposals for change to the Trade Practices Act on the 1985 EC directive for the purposes of bringing Australia's product liability laws into line with international standards and to avoid excessive litigation. The Australian Law Reform Commission had also proposed to the government that a manufacturer should be liable even if there was no defect in the goods.

However, business lobby groups, led by the Business Council of Australia (BCA) strongly opposed the onus of proof reversal. According to a newspaper article (The Weekend Australian, 1992) the BCA "said it would lead to a glut of claims, higher insurance premiums and add-on costs and less innovative products." Consequently Senator Tate scrapped the reversal of onus of proof clause in November 1991.

As it now stands the new legislation ensures that the consumer is better protected without causing the balance of proof to swing in favour of consumers. An action will arise where:

- a consumer has suffered some loss or damage; and

- $\quad$ a product causes this loss or damage; and

- $\quad$ the loss or damage suffered did not result solely from the product being used unreasonably.

Those held to be liable include:

the corporation that actually manufactures the goods; or

the corporation that holds itself out to the public as the manufacturer; or

another person promoting the goods as goods manufactured by the corporation; or

the corporation not being the actual manufacturer who imports the goods into Australia, where the true manufacturer has no place of business in Australia.

Each person in the supply chain is liable unless within a reasonable time the manufacturer or producer or a person from whom the product was acquired can be identified.

Several defences to an action under the Act are available however the following are those most probably appropriate in the case of a software developer where it can show: 
(a) that the product was not defective at the time of supply; or

(b) that the product was defective only because it complied with mandatory standards; or

(c) that the state of scientific and technical knowledge at the time the product was put into circulation was not such as to enable the existence of the defect to be discovered, i.e., a "state of the art" defence.

Under the new Act a consumer would only need to show that loss or damage had been caused by reasonable use of the software. The onus of proof then shifts to the software developer to prove one of the defences available to it.

Equally a consumer could bring a cause of action in negligence although the consumer would have a greater onus of proof. An important consideration, in deciding a course of action, is the realisation that a manufacturer cannot contract out of the new product liability addition to the Act, while, by using appropriate disclaimers, the manufacturer could contract out of negligence.

It should be noted that there is no threshold level for a liability action under Part V Div 2A of the Act, nor is there any ceiling on the level of damages which are potentially recoverable from a manufacturer. This contrasts with the EC Directive where Article 9 provides for both, although it is optional for member states.

\section{A "STATE OF THE ART" DEFENCE}

I.T. professionals involved in the design and development of safety-critical or security-critical software application systems recognise that such systems cannot be implemented with 100 percent assurance of either safety or security. Consequently, it is imperative that those organisations and personnel involved in the development life cycle do everything in their power to improve the dependability of the delivered critical software system.

Adherence to existing software standards in the development of critical software systems therefore would appear to represent an appropriate "state of the art" defence strategy for developers. Standards exist in the security field (ITSEC and TCSEC), in safety (IEC 1508), within industrial areas (for example aviation, nuclear, defence) as well as in quality (ISO 9000 series). Both the safety and security standards have a product focus while the quality standards are process directed.

Underwood [1995b] defines a hierarchical quality based certification framework that could be applied to those systems falling within the ALARP area of tolerable risk [Engineering Council 1993]. The certification framework, illustrated in Appendix 1, reuses relevant available standards and concepts, though in a unique, integrated, hierarchical manner. The framework requires that an organisation demonstrate that quality management systems are in place in the development organisation, that processes have been defined together with quantitative measures to aid the continuous improvement of the identified processes, and that adequately trained personnel, with appropriate industry experience, are involved throughout the development life cycle, and, in the assessment and certification stage. Such an approach recognises that much of the trust that we are able to place in a critical system stems from the quality of the people involved in the development of the system. 


\section{SUMMARY}

The introduction of the new product liability regime into the Australian Trade Practices Act prompted by the EC Product Liability Directive makes legal proceedings fairer and simpler for consumers who suffer loss or injury because of defective products. The amended Act has resulted in a shift in the onus of proof away from the consumer to the manufacturer. The liability of manufacturers will increase particularly in those cases where fault by the manufacturer was previously required as an element of a cause of action. Software developers or importers of software throughout the world will incur a substantial increase to exposure under the new legislation. Of necessity, top management must ensure that they are in a position to defend themselves against an action through, for example, adherence to a framework of standards and techniques that reflect the 'state of the art' in the industry.

Further support for management's increased responsibility is provided by Thomsett [1994, p. 4] who proposed that all I.T. groups are evolving through four stages with respect to control over information technology, namely, Dark Age, Tokenism, Pay Back and Partnership. He argues that management is now moving into the third stage of the model, that is, Pay Back or movement from I.T. control to business control . As a consequence an emphasis is now being placed on project management and quality with a concomitant requirement for management to accept liability for related I.T. application systems.

Management has a responsibility to ensure that the mechanisms are in place to support a 'state-of-the-art' defence in the event of litigation arising out of incorrect operation of a computer system. This requires the implementation of quality controls conforming to the ISO9000 series of standards, as well as the employment of professional I.T. staff who have the qualifications and experience necessary to perform their employment related tasks.

\section{ACKNOWLEDGMENTS}

In a lecture to a group of undergraduate students discussing Computer Contracts, Adrian McCullagh, now a Senior Associate with a Queensland law firm, confirmed my concerns with regards to the legal implications for software developers. Since then he has helped me occasionally in understanding the subtle intricacies of the Trade Practices Act.

It is further acknowledged that this paper reflects a presentation made at the 1995 SEARCC conference held in Colombo, Sri Lanka.

\section{REFERENCES}

Engineering Council. (1993) Guidelines on Risk Issues, The Engineering Council, February 1993.

European Communities (1985) Council Directive of 25 July 1985 on the approximation of the laws, regulations and administrative provisions of the Member States concerning liability for defective products, Official Journal of the European Communities, 28, No. L 210, 29-33, August 7.

Hall, Michael. (1995) Court decision Paves Way for Software Product Liability Claims, ACS Victorian Bulletin, p. 9, January/February.

Healey, Deborah. (1993) Australian Trade Practices Law, 2nd Edition, CCH Australia, 
Sydney.

Thomsett, Rob. (1994) Managing the new Information Technology revolution, The Thomsett Company.

Trade Practices Amendment Bill (No 2) 1991, para 1.

Underwood, Alan. (1995a) Legal Liability of Software Developers, SEARCC'95 Conference Proceedings, 458-466, Colombo - Sri Lanka, September 5-8.

Underwood, Alan. (1995b) A Framework for Certifying Critical Software Systems, First Annual ENCRESS Conference on Safety and Reliability of Software Based Systems, September.

The Weekend Australian, p. 9, May 9-10, 1992.

\section{BIOGRAPHY}

Alan Underwood has been employed in all facets of the computing industry over the past twenty-nine years. He is Associate Professor in Information Systems, Education Co-ordinator and Director of the National Co-operative Research Centre in Distributed Systems Technology at the Queensland University of Technology in Brisbane.

Professor Underwood is a past National President of the Australian Computer Society (ACS) and a past Chairman of the ACS(Q1d) Branch. Currently he is the National Director of the ACS Professional Board responsible for the Practising Computer Professional (PCP) and Certification programmes offered by the ACS. He is also Assistant Secretary General of the South East Asian Regional Computer Confederation (SEARCC) and a foundation member of the Special Regional Interest Group in Professional Standards. 